\title{
Clinical evaluation of therapeutic efficacy of selected chemical preparations in the treatment of dentine hypersensitivity in patients utilizing fixed dental prostheses
}

\author{
Ocena kliniczna skuteczności terapeutycznej wybranych preparatów \\ chemicznych w leczeniu nadwrażliwości zębiny u pacjentów użytkujących \\ stałe uzupelnienia protetyczne
}

\author{
Bożena Jedynak', Robert Jedynak ${ }^{2}$ \\ ${ }^{1}$ Katedra Protetyki Stomatologicznej Warszawskiego Uniwersytetu Medycznego \\ Head: prof. dr hab. n. med. Elżbieta Mierzwińska-Nastalska \\ 2 Prywatna Praktyka Stomatologiczna w Warszawie \\ Head: dr n. med. Bożena Jedynak
}

KEY WORDS:

dentine hypersensitivity, fixed dental restorations, chemical preparations

\section{Summary}

Introduction. Several dental procedures may lead to the development of dentine hypersensitivity. In patients undergoing prosthetic rehabilitation, hypersensitivity may be secondary to mechanical damage to hard tissues of the tooth as a result of grinding teeth to retain fixed dental restorations. Chemical methods are usually used to alleviate dentine sensitivity. Knowledge of the clinical efficacy of the available chemical preparations will enable the doctor to choose the most optimal desensitizing agent.

Aim of the study. To perform clinical evaluation of the therapeutic efficacy of selected chemical preparations: Duraphat and Seal \& Protect varnish, Tooth Mousse paste and Green Or liquid in the treatment of dentinal hypersensitivity in patients using fixed prosthetic restorations.

Material and methods. The size of the study group was 25 individuals with dentine hypersensitivity (100 teeth). Each patient who qualified for the study had four teeth with
HASŁA INDEKSOWE:

nadwrażliwość zębiny, uzupełnienia stałe, preparaty chemiczne

\section{Streszczenie}

Wstęp. Do rozwoju nadwrażliwości zębiny moga prowadzić niektóre procedury $i$ zabiegi stomatologiczne. U pacjentów leczonych protetycznie może być następstwem mechanicznego uszkodzenia twardych tkanek zęba w wyniku szlifowania zębów pod state uzupetnienia protetyczne. Do znoszenia wrażliwości zębiny najczęściej stosuje sie metody chemiczne. Znajomość skuteczności terapeutycznej dostępnych preparatów chemicznych pozwoli lekarzowi na wybór najbardziej optymalnego środka desensytyzujacego.

Cel pracy. Celem pracy byla ocena kliniczna skuteczności leczniczej wybranych preparatów chemicznych: lakieru Duraphat i Seal\&Protect, pasty Tooth Mousse i preparatu złożonego Green Or $w$ znoszeniu nadwrażliwości zębiny u pacjentów użytkujacych stałe uzupetnienia protetyczne.

Material i metody. Liczebność badanej grupy wynosiła 25 osób z nadwrażliwościa zębiny (100 zębów). Pacjent zakwalifikowany do badania posiadat 4 zęby ze wzmożona wrażliwościa zębiny, 
increased dentine sensitivity and underwent a single application of chemical preparations (each sensitive tooth was treated with a different chemical agent). The therapeutic efficacy of the preparations was assessed on the VAS scale by comparing the degree of pain intensity following mechanical and thermal stimuli at four occasions: directly after application of the preparations and during review appointments after 3 and 7 days, and 6 weeks.

Results. Tooth Mousse paste brought instant relief to the patient directly after application (100\% pain reduction in patients with low dentine sensitivity, and $85-90 \%$ with high sensitivity) and showed long-lasting effect (after 6 weeks, the therapeutic effect decreased by 1.5-10 percent compared to the results achieved directly after paste application). Slightly weaker (statistically insignificant) therapeutic effect was demonstrated by the Green Or preparation. The immediate relief after use in patients with low dentine sensitivity was obtained in $92.5 \%$-98.5\% of sensitive teeth. In the group with severe sensitivity, alleviation was achieved in 80-88\% of cases. At review after 6 weeks, the clinical efficacy decreased by 7.5-10\%. Fluoride varnishes (Duraphat and Seal \& Protect) provided immediate relief after application in $68-75 \%$ of sensitive teeth in patients with low dentine sensitivity. When sensitivity was intense, the therapeutic effect was on the level of 25-36.4\% of teeth not responding to the applied stimuli. The therapeutic effect after 6 weeks was maintained at $66.6-70 \%$ for teeth with low sensitivity and 45.5-56.6\% for teeth with strong dentine sensitivity.

Conclusions. The highest therapeutic efficacy in alleviating dentine sensitivity in patients using fixed prosthetic restorations was demonstrated by Tooth Mousse paste. Slightly weaker (not statistically significant) therapeutic efficacy was demonstrated by the Green Or preparation. The weakest effect at all stages of the study was noted for fluoride varnishes, which had a slower onset and weaker action than the combined preparations (statistically significant differences), and their therapeutic effect clearly decreased over time. na które aplikowano jednorazowo preparaty chemiczne (każdy wrażliwy ząb byt leczony innym środkiem chemicznych u tego samego pacjenta). Skuteczność lecznicza preparatów oceniano porównując stopień natężenia bólu na bodźce mechaniczne i termiczne na czterech wizytach: bezpośrednio po aplikacji preparatów $i$ w badaniu kontrolnym (przeprowadzonym po 3 i 7 dniach oraz po 6 tygodniach).

Wyniki. Pasta Tooth Mousse szybko przynosita ulge natychmiast po aplikacji (100\% redukcji bólu u pacjentów z niska wrażliwościa i 85-90\% $z$ silna wrażliwościa zębiny) oraz wykazywata dtugotrwate działanie (po 6 tygodniach efekt leczniczy spadt o 1,5-10\% procent $w$ porównaniu z wynikami osiagniętymi bezpośrednio po aplikacji pasty). Nieznacznie stabsza (nieistotna statystycznie) skuteczność terapeutyczna wykazywat preparat Green Or. Natychmiastowa ulge po zastosowaniu u osób z niska wrażliwościa zębiny przynosit w 92,5\%-98,5\% wrażliwych zębów. $W$ grupie o silnej wrażliwości wyniki kształtowaty się na poziomie 80-88\% skuteczności. W badaniu kontrolnym po 6 tygodniach skuteczność kliniczna obniżta się o 7,5-10\%. Lakiery fluorowe (Duraphat i Seal\&Protect) natychmiastowa ulge bezpośrednio po aplikacji przynosity w 68-75\% wrażliwych zębów u osób z niska wrażliwościa zębiny. W grupie zębów o silnej wrażliwości efekt leczniczy ksztaltowat sie na poziomie 25-36,4\% zębów niewrażliwych na badane bodźce. Efekt leczniczy po 6 tygodniach utrzymywat się na poziomie 66,6-70\% dla zębów o niskiej wrażliwości i 45,5-56,6\% dla zębów z silna wrażliwościa zębiny.

Wnioski. Najwyższą skutecznościa leczniczą w znoszeniu wrażliwości zębiny u pacjentów użytkujacych stałe uzupetnienia protetyczne charakteryzowata sie pasta Tooth Mousse, nieznacznie stabsza (nieistotna statystycznie) skuteczność terapeutyczna wykazywat preparat Green Or. Najstabsze dziatanie na wszystkich etapach badania odnotowano dla lakierów fluorowych. Działaty wolniej i stabiej od preparatów złożonych (wyniki byty istotne statystycznie) oraz ich efekt terapeutyczny wyraźnie stabł w czasie. 


\section{Introduction}

Dentine hypersensitivity is a common health problem affecting the adult population, and is one of the main reasons as to why patients visit a dentist. According to epidemiological studies, $3.8 \%$ to $74 \%$ of the population of adult patients in the world suffer from this condition. ${ }^{1,2}$ The pain complaints caused by increased dentine sensitivity occur most often between the age of 30 to 40 years, most often in people with non-carious lesions and also in patients with periodontal disease. ${ }^{2}$ The aetiology of dentine hypersensitivity is multifactorial and not completely understood. For its initiation, the coexistence of the three elements is necessary: dentine exposure, the opening of the dentinal tubules orifices and the preservation of their patency in the medial direction. ${ }^{3-5}$ Currently, dentists can choose from a number of methods designed to combat dentine hypersensitivity (chemical methods, ozone therapy, ionophoresis, laser therapy). 6,7 The key role in the treatment of pain caused by the sensitivity of dentine is played by chemicals intended for professional use by a doctor in a dental office or for use at home by a patient during daily oral hygiene activities. ${ }^{8,9}$ The treatment of dentinal hypersensitivity with chemical methods is based on the hydrodynamic theory, and consists in using preparations whose chemical components (e.g. potassium ions) depolarize nerve receptors and reduce conductivity, or form insoluble complexes that close the external orifices and obliterate open dentinal tubules. , $^{4,10-14}$ Some activities and dental procedures may lead to dentinal hypersensitivity. Among the iatrogenic factors, the following should be mentioned: teeth whitening treatments, scaling and polishing of teeth, curettage, too long etching or insufficient rinsing of the etchant, and dehydration of dentine in the conservative treatment of teeth. ${ }^{2,15}$ In patients

\section{Wstęp}

Nadwrażliwość zębiny (ang.dentin hypersensitivity) jest powszechnym problemem zdrowotnym populacji osób dorosłych i należy do głównych schorzeń, z jakimi zgłaszają się pacjenci do lekarza dentysty. Według badań epidemiologicznych z tym schorzeniem boryka się od 3,8 do 74\% populacji dorosłych pacjentów na świecie. ${ }^{1,2}$ Dolegliwości bólowe wywołane wzmożoną wrażliwością zębiny występują najczęściej między 30 a 40 rokiem życia, najczęściej u osób z ubytkami niepróchnicowego pochodzenia oraz u pacjentów z chorobami przyzębia. ${ }^{2}$ Etiologia nadwrażliwości zębiny jest wieloczynnikowa i nie do końca poznana. Do jej zainicjowania niezbędne jest współwystępowanie trzech elementów: obnażenie zębiny, otwarcie ujść kanalików zębinowych oraz zachowana ich drożność w kierunku domiazgowym. ${ }^{3-5}$ Obecnie lekarze dentyści mają duży wybór metod i sposobów leczenia wrażliwości zębiny (metody chemiczne, ozonoterapia, jonoforeza, laseroterapia). ${ }^{6,7}$ Kluczową rolę w znoszeniu dolegliwości bólowych wywołanych wrażliwością zębiny odgrywają środki chemiczne przeznaczone do profesjonalnego zastosowania przez lekarza $\mathrm{w}$ gabinecie stomatologicznym lub do stosowania w domu przez pacjenta $\mathrm{w}$ codziennych zabiegach higienizacyjnych jamy ustnej. ${ }^{8}{ }^{8}$ Leczenie nadwrażliwości zębiny metodami chemicznymi jest oparte na teorii hydrodynamicznej i polega na stosowaniu preparatów, których składniki chemiczne (np. jony potasowe) depolaryzują receptory nerwowe i zmniejszają przewodnictwo lub tworzą nierozpuszczalne kompleksy, które zamykają ujścia zewnętrzne i obliterują otwarte kanaliki zębinowe. ${ }^{4,5,10-14}$ Do powstania nadwrażliwości zębiny mogą prowadzić niektóre procedury i zabiegi stomatologiczne. Spośród czynników jatrogennych należy wymienić: zabiegi wybielania zębów, skaling i polerowanie zębów, kiretaż, zbyt długie wytrawianie 
treated prosthetically, increased dentine sensitivity is the result of dentine exposure and opening of the dentinal tubules as a result of mechanical damage to the hard tissues of the tooth. Abrasion of enamel, dentine or cementum may occur at the point of contact of structural components of removable dentures, e.g. prosthetic clamps, rests, denture plates with preserved dentition. ${ }^{2,16,17}$ Moreover, dentine hypersensitivity may initiate selective tooth grinding for the treatment of traumatic occlusion, alignment of the disturbed centric and/or eccentric occlusal plane, preparation of teeth for fixed restorations (veneers, inlays, onlays, crowns), before positioning fixed restorations and/or after cementing them. Clinical effectiveness of relieving dentine sensitivity depends on the dentist choosing the best method. When selecting chemical agents dedicated to fight dentinal hypersensitivity, the physician should be guided by the therapeutic effectiveness (rapid onset, strength and permanence of the desensitising effect are the determinants) and ease of application, availability and price. Dentinal hypersensitivity is a disorder that tends to relapse, which is why it is important to provide the patient with information on the role of diet and hygiene habits as factors causing dentine hypersensitivity. ${ }^{18,19}$

\section{Aim of the study}

Evaluation of the therapeutic effectiveness of selected chemical agents: fluoride varnish (Seal\&Protect, Duraphat) and Tooth Mousse paste and Green Or compound preparation in the alleviation of dentinal hypersensitivity in patients using fixed prosthetic restorations.

\section{Material and methods}

The study group included 25 people (15 women $-60 \%$ and 10 men $-40 \%$ ), 100 teeth i/lub niedostateczne wypłukanie wytrawiacza oraz przesuszanie zębiny w leczeniu zachowawczym zębów. ${ }^{2,15} \mathrm{U}$ pacjentów leczonych protetycznie wzmożona wrażliwość zębiny jest wynikiem obnażenia zębiny i otwarcia kanalików zębinowych w następstwie uszkodzenia mechanicznego twardych tkanek zęba. Abrazja szkliwa, zębiny lub cementu może powstać w miejscu kontaktu elementów konstrukcyjnych ruchomych protez zębowych, np. klamer protetycznych, cierni, płyt protez z zachowanym uzębieniem. ${ }^{2,16,17}$ Ponadto nadwrażliwość zębiny może zainicjować zabieg selektywnego szlifowania zębów w celu leczenia zgryzu urazowego, wyrównania zaburzonej płaszczyzny zwarcia centrycznego i /lub ekscentrycznego, opracowania zębów do uzupełnień stałych (licówki, wkłady koronowe, nakłady, korony), przed osadzeniem stałych uzupełnień protetycznych i/lub po ich zacementowaniu. Od trafności wyboru przez lekarza stomatologa optymalnego sposobu znoszenia wrażliwości zębiny zależy skuteczność kliniczna. Przy doborze środków chemicznych do znoszenia wrażliwości zębiny lekarz powinien kierować się skutecznością terapeutyczną (wykładnikiem jest szybkość działania, siła i trwałość efektu desensytyzującego) oraz łatwością aplikacji, dostępnością i ceną. Nadwrażliwość zębiny jest schorzeniem, które wykazuje tendencję do nawrotu, dlatego ważne znaczenie ma przekazanie pacjentowi informacji na temat roli diety i nawyków higienicznych w inicjacji nadwrażliwości zębiny. ${ }^{18,19}$

\section{Cel pracy}

Ocena skuteczności leczniczej wybranych środków chemicznych: lakierów fluorowych (Seal\&Protect, Duraphat) oraz pasty Tooth Mousse i preparatu złożonego Green Or w znoszeniu nadwrażliwości zębiny u pacjentów użytkujących stałe uzupełnienia protetyczne. 
Tabela 1. Distribution of the examined patients acc. to age and gender

\begin{tabular}{|c|c|c|c|}
\hline \multirow{2}{*}{ Gender } & \multirow{2}{*}{ Number of patients(\%) } & \multicolumn{2}{|c|}{ Age of patients } \\
\cline { 3 - 4 } & & Overall & Mean age \\
\hline Female & $15(60 \%)$ & $20-73$ & 40.2 \\
\hline Male & $10(40 \%)$ & $18-71$ & 37.4 \\
\hline
\end{tabular}

Tabe la 2. Tested material

\begin{tabular}{|c|c|c|c|}
\hline $\begin{array}{c}\text { Number of } \\
\text { patients }\end{array}$ & $\begin{array}{l}\text { Number of } \\
\text { teeth in total }\end{array}$ & $\begin{array}{l}\text { Number } \\
\text { of teeth }\end{array}$ & Clinical diagnosis \\
\hline \multirow{7}{*}{25} & \multirow{7}{*}{100} & \multicolumn{2}{|c|}{$\begin{array}{c}\text { Dental hypersensitivity after their preparation for fixed restorations } \\
\text { and before and/or after cementing }\end{array}$} \\
\hline & & 5 & - inlays, onlays \\
\hline & & 2 & - veneers \\
\hline & & 31 & - prosthetic crowns \\
\hline & & 22 & - prosthetic bridges \\
\hline & & 17 & - after cementing temporary fixed prosthetic restorations \\
\hline & & 23 & - after cementing permanent fixed prosthetic restorations \\
\hline
\end{tabular}

in total. Patients' age ranged from 18 to 74 years. A comparison of the test group in the age and gender category is shown in Table 1. The average age of patients was 37.8 (standard deviation SD-16.8). The material of the test group is included in Table 2. Patients who had at least 16 natural teeth of which at least 4 teeth manifested increased dentine sensitivity were included in the study. In every patient, the following chemical preparations tested in this study were applied, i.e.: Duraphat (ColgatePalmolive, Germany), Seal\&Protect (Dentsply DeTrey, Germany), Green Or (Italmed, Italy), Tooth Mousse (GC Corporation, Japan). Each chemical preparation was applied to a different sensitive tooth in the same patient. The people qualified for the study were of good general health, did not take any medications, did not use home-made methods to relieve dentine sensitivity or whitened

\section{Material i metoda}

Liczebność badanej grupy wynosiła 25 osób, w tym 15 kobiet (60\%) i 10 mężczyzn (40\%). Badane osoby mieściły się w przedziale wiekowym od 18 do 74 roku życia. Zestawienie grupy badanej z podziałem na wiek i płeć przedstawiono w tabeli 1. Średnia wieku pacjentów wynosiła 37,8 lat (odchylenie standardowe SD-16,8). Materiał grupy badanej zawarty został $\mathrm{w}$ tabeli 2. W badaniu wzięli udział pacjenci, którzy mieli zachowanych minimum 16 zębów naturalnych i co najmniej 4 zęby wykazywały wzmożoną wrażliwość zębiny. U każdego pacjenta aplikowano wszystkie preparaty chemiczne badane w niniejszej pracy tj.: Duraphat (ColgatePalmolive, Niemcy), Seal\&Protect (Dentsply DeTrey, Niemcy), Green Or (Italmed, Włochy), Tooth Mousse (GC Corporation, Japonia). Każdy preparat chemiczny stosowano na inny 
Ta b e la 3. Distribution of the examined teeth depending on the position in the dental arch

\begin{tabular}{|l|c|c|c|}
\hline \multicolumn{1}{|c|}{ Teeth group } & $\begin{array}{c}\text { Number of teeth overall } \\
\text { and in (\%) }\end{array}$ & $\begin{array}{c}\text { Number of teeth in the } \\
\text { maxilla 58 }(\%)\end{array}$ & $\begin{array}{c}\text { Number of teeth in the } \\
\text { mandible 42 (\%) }\end{array}$ \\
\hline Incisors & $21(21 \%)$ & $13(8 \%)$ & $8(6 \%)$ \\
\hline Canines & $31(31 \%)$ & $19(20 \%)$ & $12(16 \%)$ \\
\hline Premolars & $23(23 \%)$ & $14(16 \%)$ & $9(13 \%)$ \\
\hline Molars & $25(25 \%)$ & $11(12 \%)$ & $14(9 \%)$ \\
\hline
\end{tabular}

teeth with vital pulp. The distribution of the examined teeth in the dental arch is shown in Table 3. The examined patients reported pain complaints during inhalation of cold air, consumption of food and/or beverages at various temperatures (cold, warm), acidic or sweet foods, drinking carbonated drinks and brushing teeth. Dentine hypersensitivity was due to prosthetic treatment: preparation of teeth with vital pulp for fixed restorations: veneers, inlays, onlays, crowns and bridges and before the placement of fixed prosthetic restorations and/or after their cementation. The examined patients determined the intensity of pain following application of two stimulated factors: mechanical (touch of a blunt probe and its movement along a sensitive tooth surface) and thermal (stream of cold air from air spray within 10 seconds). The patients determined the subjective pain sensations using a descriptive VAS (visual-analogue scale) by moving the slider on a $10 \mathrm{~cm}$ ruler, the 0 point on the scale indicated no pain, and 10 was the maximum level. The patient was supposed to indicate with their finger on the presented scale or set the slider to a point that corresponded with the intensity of the pain they felt. The application of chemical preparations on the surface of the tested teeth was carried out in accordance with the manufacturer's instructions given in the manual. Before using the chemical preparations the teeth surface was carefully prepared for the application wrażliwy ząb w jamie ustnej u tego samego pacjenta. Osoby zakwalifikowane do badania były ogólnie zdrowe, nie przyjmowały żadnych leków, nie stosowały domowych sposobów znoszenia wrażliwości zębiny i wybielania zębów z żywą miazgą. Rozkład badanych zębów w łuku zębowym przedstawiono w tabeli 3. Badane osoby zgłaszały dolegliwości bólowe podczas wdychania zimnego powietrza, spożywania pokarmów i/lub napojów o różnej temperaturze (zimne, ciepłe), kwaśnych lub słodkich pokarmów, picia napojów gazowanych oraz szczotkowania zębów. Nadwrażliwość zębiny powstała w wyniku przeprowadzonego leczenia protetycznego: opracowania zębów z żywą miazgą pod uzupełnienia stałe: licówki, wkłady, nakłady, korony i mosty oraz przed osadzeniem stałych uzupełnień protetycznych i/lub po ich zacementowaniu. Osoby badane określały natężenie bólu na dwa bodźce stymulowane: mechaniczny (dotyk tępego zgłębnika i jego przesuwanie po wrażliwej powierzchni zęba) i termiczny (strumień zimnego powietrza z dmuchawki dentystycznej w ciągu 10 sekund). Subiektywne doznania bólowe pacjenci określali posługując się opisową skalą wizualno-analogową VAS (ang. Visual Analogue Scale). Wizualna skala analogowa przypominała linijkę o długości $10 \mathrm{~cm}$. Punkt 0 na skali oznaczał zupełny brak dolegliwości bólowych, a punkt 10 maksymalny, najsilniejszy do wyobrażenia ból. Pacjent miał za zadanie wskazać na przedstawionej mu skali za pomocą palca lub ustawić suwak w miejscu, które 
- dental calculus and bacterial plaque were removed from the tooth surface, washed with water and dried, then the drug was applied with a disposable cotton applicator to the tooth surface and lightly rubbed in. In the case of fluoride varnishes, if the decrease in dentine hypersensitivity after application of one layer was lower than 2 points on VAS scale, the second layer of varnish was applied. The Seal\&Protect varnish, when applied to the tooth surface, was exposed to light from LCU for 10 seconds. The assessment of the severity of pain to the test stimuli was carried out on subsequent visits: after scaling, immediately after the application of chemical preparations and on control visits carried out after 3 and 7 days and after 6 weeks of their application. The initial sensitivity of dentine was examined after teeth grinding and then the preparations were applied to the prepared dentine and the degree of sensitivity of dentine was reassessed. The next step was to make temporary restorations using a direct method (from an impression taken with silicone material before the preparation of teeth) and place them on the prepared teeth using temporary cement without eugenol (Temp-Bond NE, Kerr) for the period of making long-term prosthetic restorations. The use of eugenol-free temporary cement to bond crowns was intended to eliminate its anaesthetic and analgesic effect. The tooth sensitivity test was carried out after 3 days during the inspection of the metal or zirconium base of the target prosthetic restoration, carried out after the removal of temporary crowns and tooth cleaning from the remains of temporary cement. Then the temporary crowns were cemented again. Another dentine sensitivity assessment was performed 7 days after the application of the chemical preparations. Temporary prosthetic restorations were removed from the teeth, teeth were cleaned, the sensitivity of dentine was examined and permanent restorations odpowiadało intensywności bólu, jaki odczuwał. Aplikację preparatów chemicznych na powierzchnię testowanych zębów przeprowadzono zgodnie z zaleceniami producenta podanymi w instrukcji. Przed zastosowaniem środków chemicznych przygotowano powierzchnię zębów wykonując zabieg usunięcia kamienia nazębnego, osadu i płytki bakteryjnej z powierzchni zęba, przemyciu wodą i osuszeniu. Następnie nanoszono preparat jednorazowym, bawełnianym aplikatorem na powierzchnię zęba i lekko go wcierano. W przypadku lakierów fluorowych, jeśli spadek wrażliwości zębiny po jednokrotnym lakierowaniu był niższy niż 2 punkty w skali VAS nakładano drugą warstwę lakieru. Lakier Seal\&Protect po nałożeniu na powierzchnię zęba był naświetlany lampą polimeryzacyjną przez 10 sekund. Ocenę nasilenia dolegliwości bólowych na badane bodźce prowokacyjne przeprowadzono na kolejnych wizytach: po scalingu i opracowaniu zębów pod stałe uzupełnienia protetyczne, bezpośrednio po aplikacji preparatów chemicznych oraz na wizytach kontrolnych przeprowadzonych po 3 i 7 dniach oraz po 6 tygodniach od ich zastosowania. Wyjściową wrażliwość zębiny badano po oszlifowaniu zębów, następnie aplikowano preparaty na opracowaną zębinę i powtórnie oceniano stopień wrażliwości zębiny. Kolejną czynnością na tej wizycie było wykonanie uzupełnień tymczasowych metodą bezpośrednią ( $\mathrm{z}$ wycisku pobranego masą silikonową przed opracowaniem zębów) i osadzenie ich na oszlifowanych zębach przy użyciu cementu tymczasowego bez zawartości eugenolu (Temp-Bond NE, Kerr) na okres wykonania długoczasowych uzupełnień protetycznych. Zastosowanie do osadzania koron tymczasowych cementu bez zawartości eugenolu miało na celu wyeliminowanie jego działania znieczulającego i przeciwbólowego. Badanie wrażliwości zębów po 3 dniach przeprowadzono podczas kontroli podbudowy metalowej lub cyrkonowej docelowych uzupełnień protetycznych, dokonanej po zdjęciu koron tymczasowych i usunięciu 
Ta bela 4. Distribution of teeth depending on the severity of pain

\begin{tabular}{|l|c|c|c|c|}
\hline \multicolumn{1}{|c|}{$\begin{array}{c}\text { Chemical } \\
\text { preparation }\end{array}$} & $\begin{array}{c}\text { Type of stimulus } \\
\text { thermal/mechanical T/M }\end{array}$ & Group A & Group B & Group C \\
\hline Duraphat & T/M & $6 / 7$ & $9 / 10$ & $10 / 8$ \\
\hline Seal\&Protect & T/M & $5 / 6$ & $11 / 8$ & $9 / 11$ \\
\hline Green Or & T/M & $5 / 6$ & $9 / 11$ & $11 / 8$ \\
\hline Tooth Mousse & T/M & $6 / 5$ & $9 / 8$ & $10 / 12$ \\
\hline Overall & T/M & $22 / 24$ & $38 / 37$ & $40 / 39$ \\
\hline
\end{tabular}

were cemented with a glass ionomer cement (Ketac Cem, 3M ESPE). After 6 weeks, the check-up was carried out without removing the target permanent dentures. The dentine sensitivity test was performed by directing the jet of air from the air spray perpendicularly to the examined tooth surface at the level of the gingival edge of the crown. On the other hand, the dentine reaction to the mechanical stimulus was examined by moving the probe along the surface of the tooth along the gingival step of the prosthetic crown. All teeth were prepared with supragingival or gingival step in order to reduce the risk of exceeding the biological width when placing the subgingival edge of prosthetic crowns as a factor predisposing to the initiation of dentine hypersensitivity. The examined teeth were divided into three groups depending on the severity of pain to a thermal and mechanical stimulus (Table 4). Teeth with low sensitivity of dentine in the range of 1-3 on the VAS scale were assigned to group A. Group B had teeth with an average dentinal sensitivity of 4 to 7 on the VAS scale. Group $\mathrm{C}$ included teeth with strong sensitivity (8-10 on the VAS scale).

\section{Statistical analysis}

The obtained results of the study were subjected to statistical analysis using the statistical package STATISTICA 8.0. Statistical oraz oczyszczeniu zębów z pozostałości cementu tymczasowego. Następnie zacementowano powtórnie korony tymczasowe. Kolejną ocenę wrażliwości zębiny wykonano po 7 dniach od aplikacji preparatów chemicznych. Usunięto z zębów tymczasowe uzupełnienia protetyczne, oczyszczono zęby, zbadano wrażliwość zębiny i zacementowano długoczasowe uzupełnienia za pomocą cementu glasjonomerowego (Ketac Cem, 3M ESPE). Badanie kontrolne po 6 tygodniach było przeprowadzone bez zdejmowania docelowych stałych protez zębowych. Badanie wrażliwości zębiny przeprowadzono kierując strumień powietrza $\mathrm{z}$ dmuchawki dentystycznej prostopadle do badanej powierzchni zęba na wysokości dodziąsłowego brzegu korony. $\mathrm{Z}$ kolei reakcję zębiny na bodziec mechaniczny badano przesuwając zgłębnik po powierzchni zęba wzdłuż przebiegu dodziąsłowego stopnia korony protetycznej. Wszystkie zęby zostały opracowane ze stopniem naddziąsłowym lub dodziąsłowym w celu ograniczenia ryzyka przekroczenia szerokości biologicznej przy umieszczaniu brzegu poddziąsłowego koron protetycznych, jako czynnika predysponującego do inicjacji nadwrażliwości zębiny.

Badane zęby podzielono na 3 grupy w zależności od stopnia nasilenia dolegliwości bólowych na bodziec termiczny i mechaniczny (tabela 4). Do grupy A zakwalifikowano zęby $\mathrm{z}$ niską wrażliwością zębiny mieszczącą się w przedziale 1-3 w skali VAS. Grupa B 
Ta b e la 5. Therapeutic effectiveness of chemical preparations in group A

\begin{tabular}{|l|c|c|c|c|c|c|c|c|}
\hline \multirow{2}{*}{\multicolumn{1}{|c|}{ Examination }} & \multicolumn{2}{|c|}{$\begin{array}{c}\text { Duraphat } \\
(\%)\end{array}$} & \multicolumn{2}{c|}{$\begin{array}{c}\text { Seal\&Protect } \\
(\%)\end{array}$} & \multicolumn{2}{c|}{$\begin{array}{c}\text { Green Or } \\
(\%)\end{array}$} & \multicolumn{2}{c|}{$\begin{array}{c}\text { Tooth Mousse } \\
(\%)\end{array}$} \\
\cline { 2 - 10 } & $\mathrm{T}$ & $\mathrm{M}$ & $\mathrm{T}$ & $\mathrm{M}$ & $\mathrm{T}$ & $\mathrm{M}$ & $\mathrm{T}$ & $\mathrm{M}$ \\
\cline { 2 - 10 } & 68.6 & 72.5 & 70 & 75.5 & 92.5 & 98.5 & 100 & 100 \\
\hline $\begin{array}{l}\text { After second application } \\
\text { of fluoride varnish }\end{array}$ & 78.2 & 80 & 82.5 & 85.6 & & & & \\
\hline Control visit after 3 days & 78.2 & 75 & 80 & 72.5 & 98.5 & 100 & 100 & 98.5 \\
\hline Control visit after 7 days & 75 & 82.5 & 80 & 88.3 & 100 & 100 & 100 & 100 \\
\hline Control visit after 6 weeks & 62.5 & 66.6 & 66.6 & 70 & 90.5 & 92.5 & 98.5 & 100 \\
\hline
\end{tabular}

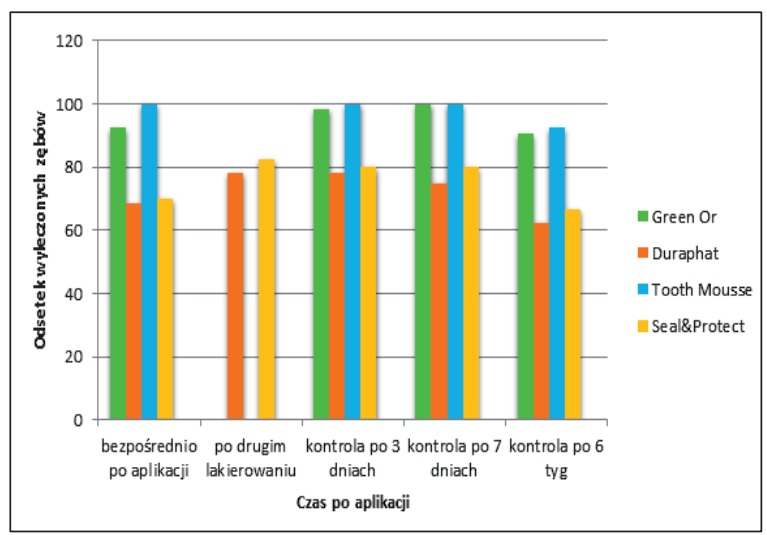

Fig. 1a. Absence of pain reaction in group $A$ to the thermal stimulus (air).

Ryc. 1a. Brak reakcji bólowej w grupie A na bodziec termiczny (powietrze).

analyses were made using the Student's t-test. The value of $\mathrm{p}<0.05$ was assumed as the level of statistical significance.

\section{Results}

The obtained results together with the evaluation of the therapeutic effectiveness of the tested chemical agents are presented separately for individual groups in Tables 5-7 and in Figures 1a and b, 2a and b, 3a and b.

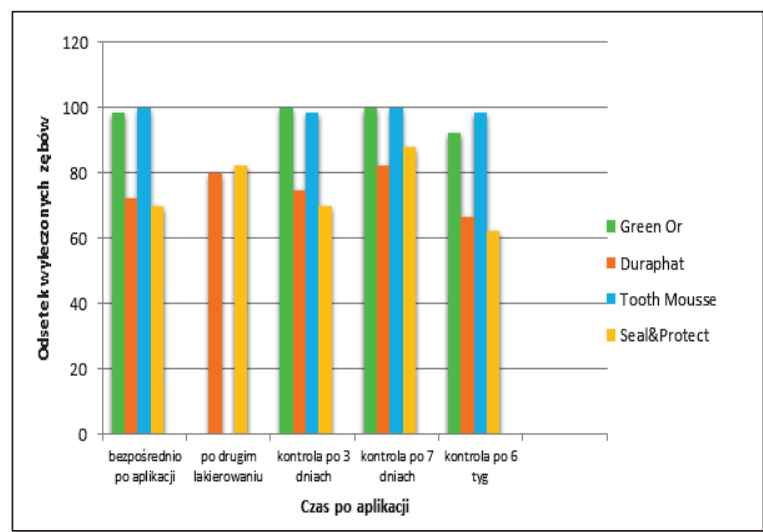

Fig. 1b. Absence of pain reaction in group $A$ to the mechanical stimulus (probe).

Ryc. 1b. Brak reakcji bólowej w grupie A na bodziec mechaniczny (dotyk zglębnika).

zawierała zęby z średnią wrażliwością zębiny wynoszącą od 4 do $7 \mathrm{w}$ skali VAS. W grupie C zawarte zostały zęby z silną wrażliwością (8-10 w skali VAS).

\section{Analiza statystyczna}

Uzyskane wyniki badań poddano analizie statystycznej z wykorzystaniem pakietu statystycznego STATISTICA 8.0. Opracowań statystycznych dokonano za pomocą testu t-Studenta. Za poziom istotności statystycznej przyjęto wartość $\mathrm{p}<0,05$. 
Ta be la 6. Therapeutic effectiveness of chemical preparations in group B

\begin{tabular}{|c|c|c|c|c|c|c|c|c|}
\hline \multirow{3}{*}{ Examination } & \multicolumn{2}{|c|}{$\begin{array}{c}\text { Duraphat } \\
(\%)\end{array}$} & \multicolumn{2}{|c|}{$\begin{array}{c}\text { Seal\&Protect } \\
(\%)\end{array}$} & \multicolumn{2}{|c|}{$\begin{array}{c}\text { Green Or } \\
(\%)\end{array}$} & \multicolumn{2}{|c|}{$\begin{array}{c}\text { Tooth Mousse } \\
(\%)\end{array}$} \\
\hline & $\mathrm{T}$ & $\mathrm{M}$ & $\mathrm{T}$ & M & $\mathrm{T}$ & $\mathrm{M}$ & $\mathrm{T}$ & $\mathrm{M}$ \\
\hline & 54.5 & 60 & 62.5 & 66.6 & 80 & 90 & 82 & 88 \\
\hline $\begin{array}{l}\text { After second application } \\
\text { of fluoride varnish }\end{array}$ & 72.5 & 75 & 70 & 78.8 & & & & \\
\hline Control visit after 3 days & 66.6 & 66.6 & 70 & 70 & 80 & 80 & 88 & 90 \\
\hline Control visit after 7 days & 62.2 & 66.6 & 66.6 & 70 & 78.2 & 78.2 & 90 & 90 \\
\hline Control visit after 6 weeks & 60 & 62.5 & 54.5 & 60 & 75 & 82 & 78.2 & 82 \\
\hline
\end{tabular}

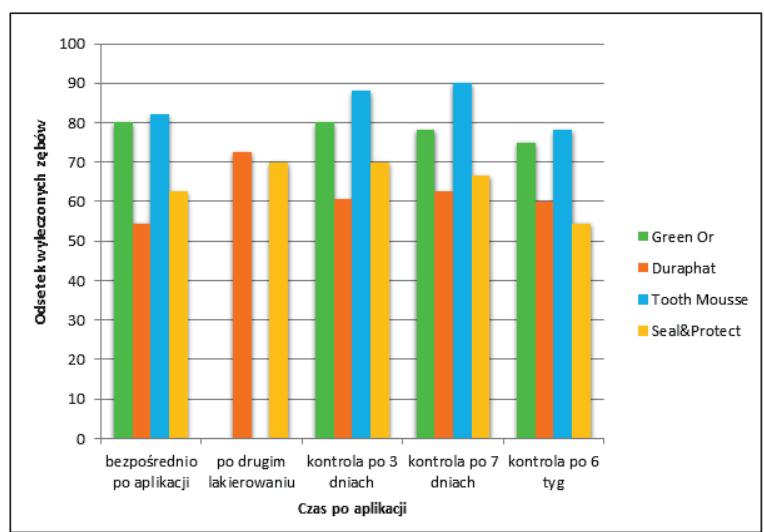

Fig. 2a. Absence of pain reaction in group $B$ to the thermal stimulus (air).

Ryc. 2a. Brak reakcji bólowej w grupie B na bodziec termiczny (powietrze).

\section{Analysis of results}

Chemical preparations play a key role in alleviating pain caused by exposed dentine to physiological stimuli when consuming beverages and foods, breathing in or brushing teeth. In order to optimise the treatment of dentinal hypersensitivity during the grinding of the abutment teeth in the preparation of fixed restorations, the clinical effectiveness of Tooth Mousse, Green Or, Duraphat and Seal $\&$ Protect was studied. The Tooth Mousse was characterised by the best desensitising parameters in the present study. Slightly

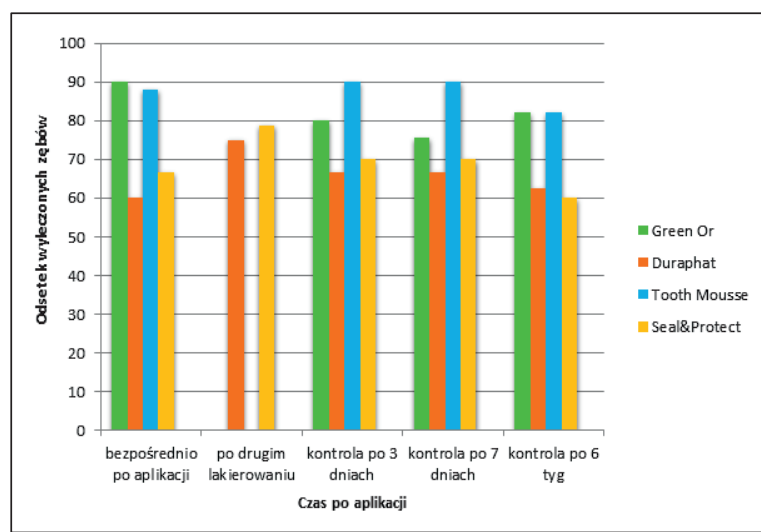

Fig. 2b. Absence of pain reaction in group $B$ to the mechanical stimulus (probe).

Ryc. 2b. Brak reakcji bólowej w grupie B na bodziec mechaniczny (dotyk zglębnika).

\section{Wyniki}

Otrzymane wyniki badań wraz oceną skuteczności terapeutycznej badanych środków chemicznych przedstawiono oddzielnie dla poszczególnych grup w tabelach 5-7 oraz na rycinach: 1a i b, 2a i b, 3a i b.

\section{Omówienie wyników}

Preparaty chemiczne odgrywają kluczową rolę $\mathrm{w}$ walce $\mathrm{z}$ dolegliwościami bólowymi obnażonej zębiny na działanie fizjologicznych bodźców podczas spożywania napojów i 
Ta b e la 7. Therapeutic effectiveness of chemical preparations in group $\mathrm{C}$; $\mathrm{P}$ - thermal stimulus (air), $\mathrm{M}-$ mechanical stimulus (probe)

\begin{tabular}{|c|c|c|c|c|c|c|c|c|}
\hline \multirow{3}{*}{ Examination } & \multicolumn{2}{|c|}{$\begin{array}{c}\text { Duraphat } \\
(\%)\end{array}$} & \multicolumn{2}{|c|}{$\begin{array}{c}\text { Seal\&Protect } \\
(\%)\end{array}$} & \multicolumn{2}{|c|}{$\begin{array}{c}\text { Green Or } \\
(\%)\end{array}$} & \multicolumn{2}{|c|}{$\begin{array}{c}\text { Tooth Mousse } \\
(\%)\end{array}$} \\
\hline & $\mathrm{T}$ & $\mathrm{M}$ & $\mathrm{T}$ & $\mathrm{M}$ & $\mathrm{T}$ & $\mathrm{M}$ & $\mathrm{T}$ & $\mathrm{M}$ \\
\hline & 36.4 & 33 & 34 & 25 & 80 & 88 & 85 & 90 \\
\hline $\begin{array}{l}\text { Next application of fluoride } \\
\text { varnish }\end{array}$ & 60.4 & 54.5 & 55 & 66.6 & & & & \\
\hline Control visit after 3 days & 62.8 & 60 & 60 & 66.6 & 82 & 90 & 82 & 90 \\
\hline Control visit after 7 days & 62.8 & 54.5 & 60 & 60 & 80 & 85 & 82 & 90 \\
\hline Control visit after 6 weeks & 56.6 & 45.5 & 52.8 & 54.5 & 72.5 & 78 & 75 & 80 \\
\hline
\end{tabular}

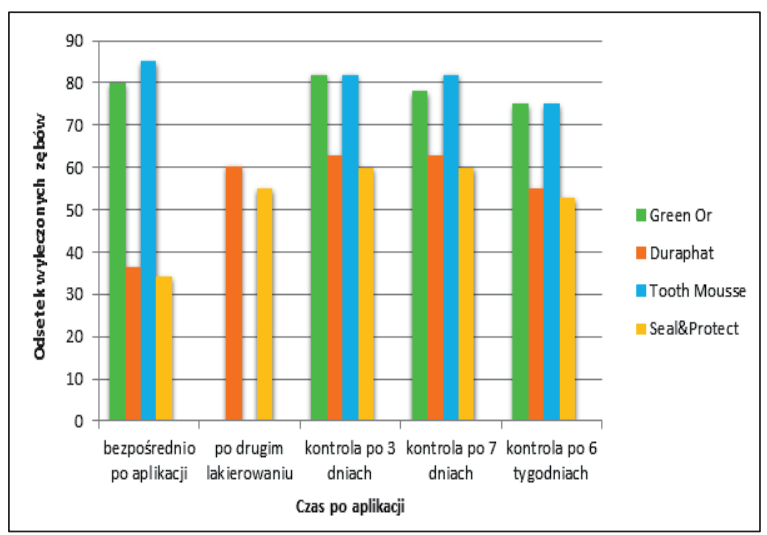

Fig. $3 a$ Absence of pain reaction in group $C$ to the thermal stimulus (air).

Ryc. 3a. Brak reakcji bólowej w grupie C na bodziec termiczny (powietrze).

weaker therapeutic properties (statistically insignificant) were demonstrated by the Green Or preparation. Noticeably worse therapeutic efficacy in the treatment of pain in exposed dentine as a result of grinding abutment teeth for fixed restorations was noted for Duraphat and Seal\&Protect fluoride varnishes. The differences concerned all the examined groups differing in the degree of dentine sensitivity (group A, B, C) and referred to each measurement point, i.e. immediately after application of the preparations, in control examinations: after 3 and 7 days and after 6 weeks. Tooth Mousse paste quickly brought

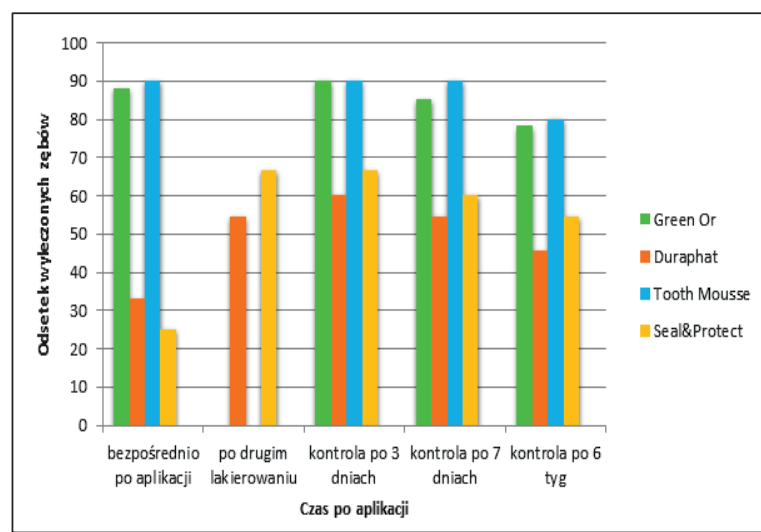

Fig. 3b. Absence of pain reaction in group $C$ to the mechanical stimulus (probe).

Ryc. 3b. Brak reakcji bólowej w grupie C na bodziec mechaniczny (dotyk zglębnika).

pokarmów, wdychania powietrza lub szczotkowania zębów. W celu zoptymalizowania leczenia nadwrażliwości zębiny podczas szlifowania zębów filarowych w wykonawstwie stałych uzupełnień protetycznych zbadano skuteczność kliniczną pasty Tooth Mousse, płynu Green Or, lakierów Duraphat i Seal\&Protect. Spośród badanych w niniejszej pracy preparatów najlepszymi parametrami odwrażliwiającymi charakteryzowała się pasta Tooth Mousse. Nieznacznie słabsze właściwości terapeutyczne (nieznamienne statystycznie) wykazywał preparat Green Or. Wyraźnie gorszą skuteczność terapeutyczną w znoszeniu dolegliwości 
relief to patients immediately after application and showed long-lasting effect. In group A, immediately after application, it completely relieved the pain in all the examined teeth. The therapeutic effect remained almost unchanged in subsequent follow-up studies. After 6 weeks of observation, only $1.5 \%$ of teeth reacted with pain to cold air, while to the probe touch the desensitising effect was still one hundred percent. In group B, the paste application to sensitive dentine brought relief to $82 \%$ of the treated teeth in response to both stimuli. In a control study after 7 days, an increase in clinical efficacy up to $90 \%$ was observed. Another study carried out after 6 weeks showed only a slight decrease in clinical effectiveness compared to the study performed immediately after application $3.8 \%$ for a thermal stimulus) and unchanged value for a mechanical stimulus. In group $\mathrm{C}$, immediate reduction of pain caused by dentinal hypersensitivity was noted in $85 \%$ of airstimulated teeth and $90 \%$ of teeth for probing. At the control visit carried out after 3 and 7 days, there was a decrease in effectiveness by $3 \%$ in response to the air stream and the unrelenting therapeutic effect on the touch of the probe. In a study performed 6 weeks after application of Tooth Mousse, the therapeutic effect was maintained on the same level for thermal stimulus and a $5.5 \%$ decrease in the therapeutic efficacy for probe compared to the results obtained immediately after applying the paste. Green Or ranked second to Tooth Mousse paste in terms of clinical effectiveness. It showed slightly weaker therapeutic effects in the performed study immediately after application and in control examinations in all the examined patients. These data were not statistically significant. In group $A$, the immediate elimination of pain after using Green Or was found in $92.5 \%$ of the examined teeth for thermal stimulus and the complete relief of pain for probing. In comparison with bólowych obnażonej zębiny w wyniku szlifowania zębów pod uzupełnienia stałe odnotowano dla lakierów fluorowych Duraphat i Seal\&Protect.

Różnice te dotyczyły wszystkich badanych grup różniących się między sobą stopniem wrażliwości zębiny (grupa A, B, C) i odnosiły się do każdego punktu pomiarowego rozłożonego w czasie tj. bezpośrednio po aplikacji preparatów, w badaniach kontrolnych: po 3 i 7 dniach oraz po 6 tygodniach. Pasta Tooth Mousse przynosiła szybko ulgę pacjentom bezpośrednio po aplikacji oraz wykazywała długotrwałe działanie. W grupie A natychmiast po zastosowaniu zniosła całkowicie dolegliwości bólowe we wszystkich badanych zębach. Efekt terapeutyczny utrzymywał się na prawie niezmienionym poziomie $\mathrm{w}$ kolejnych badaniach kontrolnych. Po okresie 6 tygodniowej obserwacji tylko $1,5 \%$ zębów reagowało bólem na zimne powietrze, natomiast na dotyk zgłębnika odnotowano nadal stuprocentowy brak reakcji. W grupie B aplikacja pasty na wrażliwą zębinę przyniosła ulgę w $82 \%$ leczonych zębów w reakcji na oba bodźce stymulujące. $\mathrm{W}$ badaniu kontrolnym przeprowadzonym po 7 dniach zaobserwowano wzrost skuteczności klinicznej do $90 \%$. Kolejne badanie przeprowadzone po 6 tygodniach wykazało nieznaczny tylko spadek efektywności klinicznej w porównaniu do badania wykonanego bezpośrednio po aplikacji ( $3,8 \%$ na bodziec termiczny) oraz niezmienioną wartość na bodziec mechaniczny. W grupie C natychmiastową redukcję dolegliwości bólowych wywołanych nadwrażliwością zębiny odnotowano w $85 \%$ badanych zębów prowokowanych powietrzem i 90\% zębów na zgłębnikowanie. Na wizycie kontrolnej przeprowadzonej po 3 i 7 dniach odnotowano spadek efektywności o 3\% w reakcji na strumień powietrza i niesłabnacy w czasie efekt terapeutyczny na dotyk zgłębnika. W badaniu wykonanym po 6 tygodniach od zastosowania pasty Tooth Mousse stwierdzono utrzymywanie się na tym 
Tooth Mousse, Green Or was characterized by a $7.5 \%$ weaker therapeutic effect in response to the stream of cold air. In the follow-up examination after 3 days, none of the teeth reacted with pain to the touch of the probe, while only $1.5 \%$ of the teeth responded with pain to the air. At the next follow-up visit carried out after 7 days, a complete reduction of pain sensations of all teeth to stimuli was observed. These results coincided with the data obtained for Tooth Mousse. After 6 weeks of observation, the therapeutic efficacy of Green Or fluid for cold air decreased only by $2 \%$ compared to the results obtained immediately after application. The reduction of pain following probe application after 6 weeks amounted to $92.5 \%$ of insensitive teeth. In group B, the results were obtained directly after the drug application, comparable with the data obtained for Tooth Mousse. Reduction of tooth dentinal hypersensitivity treated with Green Or after 3 and 7 days after application was at the level of $75-80 \%$, and was about $10 \%$ lower compared to the results achieved with Tooth Mousse. In the study carried out after 6 weeks, a slight decrease in the therapeutic effect in time was observed (about 5\% lower compared to the result obtained immediately after application). In group $\mathrm{C}$, the immediate desensitising effect after using Green Or was $5 \%$ lower in response to the stream of cold air and $2 \%$ on the touch of the probe compared to the results achieved with Tooth Mousse. In the control study after 3 days, the therapeutic effectiveness of the Green Or fluid equalled the results obtained with Tooth Mousse. On the other hand, data obtained after 7 days indicated only a slight decrease in the therapeutic effect ( $2 \%$ on thermal stimulus and $5 \%$ on probing). For comparison, results after 7 days of application of Tooth Mousse paste remained unchanged. The study carried out after a 6-week observation period resulted in a reduction in therapeutic efficacy of $7.5 \%$ samym poziomie efektu leczniczego w reakcji na bodziec termiczny i 5,5\% spadek skuteczności leczniczej na zgłębnikowanie w porównaniu z wynikami wykonanymi bezpośrednio po zastosowaniu pasty. $\mathrm{Na}$ drugim miejscu pod względem skuteczności klinicznej po paście Tooth Mousse uklasyfikował się preparat złożony Green Or. Wykazał w przeprowadzonym badaniu nieco słabsze efekty terapeutyczne bezpośrednio po aplikacji oraz w badaniach kontrolnych u wszystkich badanych pacjentów. Dane te nie były znamienne statystycznie. W grupie A natychmiastowe zniesienie dolegliwości bólowych po zastosowaniu płynu Green Or stwierdzono w $92,5 \%$ badanych zębów na bodziec termiczny i całkowite zniesienie dolegliwości bólowych na zgłębnikowanie. W porównaniu z pastą Tooth Mousse preparat Green Or charakteryzował się o 7,5\% słabszym efektem leczniczym w reakcji na strumień zimnego powietrza. W badaniu kontrolnym po 3 dniach nadal nie reagowały bólem wszystkie zęby na dotyk zgłębnika, natomiast tylko 1,5\% zębów odpowiadało bólem po stymulacji strumieniem powietrza. Na kolejnej wizycie kontrolnej przeprowadzonej po 7 dniach zaobserwowano całkowitą redukcję doznań bólowych wszystkich zębów na badane bodźce i wyniki te pokrywały się z danymi uzyskanymi dla pasty Tooth Mousse. Po 6 tygodniach obserwacji tylko o $2 \%$ spadła skuteczność lecznicza płynu Green Or w odpowiedzi na zimne powietrze w porównaniu z wynikami osiagniętymi bezpośrednio po zastosowaniu preparatu. Redukcja dolegliwości bólowych na przesuwanie zgłębnika po 6 tygodniach wahała się na poziomie $92,5 \%$ niewrażliwych zębów. W grupie B bezpośrednio po zastosowaniu płynu uzyskane wyniki były porównywalne $\mathrm{z}$ danymi osiągniętymi dla pasty Tooth Mousse. Redukcja nadwrażliwości zębiny zębów leczonych preparatem Green Or po 3 i 7 dniach od aplikacji kształtowała się na poziomie $75-80 \%$ i była ok. $10 \%$ niższa w porównaniu do osiągniętych wyników dla pasty 
compared to the results immediately after application of the preparation in response to cold air and $10 \%$ for probing. The results were at the level of $2.5 \%$ lower compared to the Tooth Mousse for a stream of cold air and 2\% lower for the touch of the probe, and were statistically insignificant. In contrast, Duraphat and Seal\&Protect fluoride varnishes clearly achieved weaker results from the combined preparations, because their speed, strength and durability over time was significantly lower compared to Tooth Mousse and Green Or. This correlation occurred at all measuring points and it could be seen in each group being examined, i.e. group A, B, C. Differences in the results achieved for Duraphat and Seal\&Protect were comparable to each other. Immediate relief immediately after varnishing in group A was observed in the reaction induced by a thermal stimulus in $68.6 \%$ of teeth treated with Duraphat and $70 \%$ of teeth treated with Seal\&Protect. In comparison with Tooth Mousse and Green Or, this result was $31.4 \%$ and $24.9 \%$ lower, respectively. The reduction of pain sensations to mechanical stimuli for the above-mentioned varnishes was higher by $4-5 \%$. Repeated application of varnishes (used in the case of dentine sensitivity decrease below 2 points on the VAS scale after the application of one layer) resulted in the increase of therapeutic effectiveness by approximately $10 \%$. The results of the control examination after 3 days showed a few percent decrease in the therapeutic effects. In the study after 7 days, the data were on the level of 78.2$88,3 \%$ of the pain-free teeth for stimuli tested in this study. After 6 weeks, $66.6 \%$ teeth were pain-free following Duraphat application for both stimuli, and $62.5 \%$ of insensitive teeth for air stream and $70 \%$ for the probe touch for Seal\&Protect were observed. Compared to the results immediately after the first coating, the clinical effectiveness of the varnishes tested after 6 weeks decreased in the range from 2 to
Tooth Mousse. W badaniu przeprowadzonym po 6 tygodniach zaobserwowano nieznacznie słabnący w czasie (ok. 5\% niższy w porównaniu z wynikiem uzyskanym bezpośrednio po aplikacji) efekt terapeutyczny. W grupie $\mathrm{C}$ natychmiastowe zniesienie bólu po zastosowaniu płynu Green Or było niższe o 5\% w reakcji na strumień zimnego powietrza i $2 \%$ na dotyk zgłębnika $\mathrm{w}$ porównaniu do wyników osiągniętych dla pasty Tooth Mousse. W badaniu kontrolnym po 3 dniach skuteczność lecznicza płynu Green Or dorównała wynikom uzyskanym dla pasty Tooth Mousse. Natomiast dane osiągnięte po 7 dniach wskazały tylko nieznaczny spadek efektu terapeutycznego ( $2 \%$ na bodziec termiczny i 5\% na zgłębnikowanie). Dla porównania wyniki po 7 dniach od aplikacji pasty Tooth Mousse utrzymywały się na niezmienionym poziomie. Badanie przeprowadzone po 6 tygodniowym okresie obserwacji przyniosły obniżenie skuteczności leczniczej o 7,5\% w porównaniu z wynikami bezpośrednio po zastosowaniu preparatu $\mathrm{w}$ reakcji na zimne powietrze i $10 \%$ na zgłębnikowanie. Wyniki kształtowały się na poziomie 2,5\% niższym w porównaniu z pastą Tooth Mousse na strumień zimnego powietrza i $2 \%$ niższym na dotyk zgłębnika i były nieistotne statystycznie. Natomiast lakiery fluorowe Duraphat i Seal\&Protect wyraźnie osiągały słabsze wyniki od preparatów złożonych, gdyż ich szybkość działania, siła i trwałość w czasie była znamiennie statystycznie niższa w porównaniu z pastą Tooth Mousse i płynem Green Or. Zależność ta występowała we wszystkich punktach pomiarowych i można ją było zauważyć w każdej badanej grupie tj. grupie A, B, C. Różnice w osiąganych wynikach dla lakieru Duraphat i Seal\&Protect były porównywalne do siebie. Natychmiastową ulgę bezpośrednio po lakierowaniu w grupie A zaobserwowano w reakcji indukowanej bodźcem termicznym w 68,6\% zębów leczonych Duraphatem i $70 \%$ zębów poddanych terapii Seal\&Protect. 
$7.5 \%$ depending on the type of varnish and stimulus, and was significantly lower compared to the combined preparations. In the group with medium dentine sensitivity (group B) immediate relief after applying one layer of varnish to the sensitive tooth surface was observed in $54.5-66.6 \%$ of the teeth examined, which gives a several dozen percent weaker results compared to Tooth Mousse toothpaste and Green Or. Repeated application of varnishes increased their therapeutic effect, but the results achieved were still lower than the data obtained for combined preparations immediately after their application. In a control test performed 6 weeks after varnishing, the therapeutic effectiveness of Duraphat varnish increased by $2.5-5 \%$, and for Seal\&Protect by $9-14.5 \%$ depending on the irritant stimulus as compared to the results obtained immediately after a single application of varnish. In teeth most sensitive to stimuli (group C) after the direct application of varnish, pain was relieved in $34-36 \%$ of teeth irritated with a thermal stimulus and in 25$33 \%$ with probing. The placement of the second layer of varnish brought relief to a much larger percentage of teeth. In the control examination after 3 days, the therapeutic effectiveness of varnishes reached $60-66.6 \%$ and was lower than the values obtained for the combined preparations by $15.4-30 \%$. This difference was maintained at a similar level also in the control examination performed after 7 days and after 6 weeks.

\section{Discussion}

A review of the literature over the past decades has shown an increase in the incidence of dentine hypersensitivity in the adult population. Pain is an essential measurable parameter that determines the severity of the disease. It does, however, identify subjective feelings of existing discomfort or
W porównaniu z pastą Touut Mousse wynik ten był o 31,4\% niższy, a w stosunku do preparatu Green Or o 24,9\%. Redukcja doznań bólowych w odpowiedzi na bodziec mechaniczny dla w/w lakierów była wyższa o wartość 4-5\% w stosunku z wartościami osiągniętymi po stymulacj strumieniem powietrza. Powtórna aplikacja lakierów (stosowana w przypadku spadku wrażliwości zębiny mniejszego niż 2 punkty w skali VAS po nałożeniu jednej warstwy) przyniosła wzrost skuteczności leczniczej o ok. 10\%. Wyniki badań kontrolnych po 3 dniach wykazały kilkuprocentowy spadek efektów leczniczych. W badaniu po 7 dniach dane kształtowały się na poziomie 78,2-88,3\% zębów wolnych od bólu na badane w niniejszej pracy bodźce. Po 6 tygodniach zaobserwowano $66,6 \%$ zębów wolnych od dolegliwości bólowych poddanych terapii Duraphatem na oba bodźce oraz $62,5 \%$ niewrażliwych zębów na strumień powietrza i 70\% na dotyk zgłębnika dla preparatu Seal\&Protect. W porównaniu do wyników bezpośrednio po pierwszym lakierowaniu skuteczność kliniczna lakierów badana po 6 tygodniach obniżyła się $\mathrm{w}$ przedziale od 2 do $7,5 \% \mathrm{w}$ zależności od rodzaju lakieru i bodźca i była znacząco niższa w porównaniu z preparatami złożonymi. W grupie o średniej wrażliwości zębiny (grupa B) natychmiastową ulgę po nałożeniu na wrażliwą powierzchnię zęba jednej warstwy lakieru zaobserwowano w 54,5-66,6\% badanych zębach, co daje o kilkadziesiąt procent słabsze wyniki w porównaniu z pastą Tooth Mousse i płynem Green Or. Powtórna aplikacja lakierów zwiększyła efekt terapeutyczny lakierów, lecz osiągnięte wyniki były nadal niższe od danych uzyskanych dla preparatów złożonych bezpośrednio po ich aplikacji. W badaniu kontrolnym wykonanym po 6 tygodniach od lakierowania skuteczność lecznicza lakieru Duraphat wzrosła o 2,5-5\%, a dla preparatu Seal\&Protect o $9-14,5 \%$ w zależności od bodźca drażniącego w porównaniu do wyników uzyskanych bezpośrednio po 
pain that vary from patient to patient. There are many factors modulating and disturbing the perception of pain, e.g. mood changes, stress, depression or coexistence of systemic diseases. ${ }^{20-22}$ To evaluate the effectiveness of analgesic treatment in medicine, the visualanalogue scale (VAS) is often used, because it allows comparing the results of several systematically repeated measurements taken in a specific time period by the same patient, as well as comparing the results between different methods. ${ }^{23}$ During the tooth grinding procedure, mechanical damage to the tooth hard tissues and loss of enamel and/or dentine occurs over a large area. Preparation of teeth for prosthetic crowns involves the exposure of approximately 1-2 million dentinal tubules $\left(30,000-40,000\right.$ tubules per $1 \mathrm{~mm}^{2}$ of dentine). ${ }^{24}$ Exposed dentine is subjected to direct influence of external factors and penetration of harmful stimuli into the dental pulp. Therefore, the most common complications of prosthetic rehabilitation with permanent prosthetic restorations include loss of pulp vitality, gingivitis or increased dentine sensitivity. ${ }^{25,26}$ There is a close correlation between the degree of sensitivity of dentine and the number and diameter of open canals. In one randomised study, the authors assessed the type and frequency of complications after preparation of abutments for prosthetic crowns using different cements. A severe form of dentine hypersensitivity was found, which required endodontic treatment in $7.4 \%$ of teeth subjected to the grinding procedure. ${ }^{27}$ The development of dentine sensitivity may occur after cementation of fixed, permanent prosthetic restorations with, for example, glass ionomer cement. Polyacrylic acid contained in luting cement may widen dentinal tubules and increase the movement of the liquid, which will irritate the endings of sensory fibres in the pulp of the tooth. ${ }^{28}$ In order to reduce postoperative sensitivity, temporary crowns, jednorazowym lakierowaniu. W zębach najbardziej wrażliwych na bodźce (grupa C) po bezpośredniej aplikacji lakieru ból uległ zniesieniu w 34-36\% zębów drażnionych bodźcem termicznym i 25-33\% zgłębnikowaniem. Położenie drugiej warstwy lakieru przyniosło ulgę znacznie większemu odsetkowi zębów. W badaniu kontrolnym przeprowadzonym po 3 dniach skuteczność lecznicza lakierów sięgała 60-66,6\% i była niższa od wartości uzyskanych dla preparatów złożonych o 15,4-30\%. Różnica ta utrzymywała się na zbliżonym poziomie również $\mathrm{w}$ badaniu kontrolnym wykonanym po 7 dniach i po 6 tygodniach.

\section{Dyskusja}

$\mathrm{Na}$ podstawie przeglądu piśmiennictwa $\mathrm{z}$ ostatnich dziesięcioleci można zauważyć wzrost częstości występowania nadwrażliwości zębiny w populacji osób dorosłych. Ból jest zasadniczym parametrem mierzalnym określającym stopień nasilenia tego schorzenia. Określa jednak subiektywne, osobniczo różne u każdego pacjenta odczucia istniejącego dyskomfortu lub dolegliwości bólowych. Istnieje wiele czynników modulujących i zaburzających percepcję bólu np. zmiany nastroju, stres, depresja czy współwystępowanie chorób ogólnoustrojowych. ${ }^{20-22}$ Do oceny skuteczności leczenia przeciwbólowego w medycynie często jest wykorzystywna skala wizualno-analogowa VAS, gdyż pozwala na porównanie wyników z kilku systematycznie powtarzanych pomiarów, wykonanych w określonym przedziale czasowym przez tego samego pacjenta oraz dokonanie porównania wyników pomiędzy różnymi metodami. ${ }^{23}$ Podczas zabiegu szlifowania zębów dochodzi do mechanicznego urazu tkanek twardych zęba i utraty szkliwa i/ lub zębiny na dużym obszarze. Przygotowanie zębów w wykonawstwie koron protetycznych wiąże się z odsłonięciem około 1-2 milionów kanalików zębinowych (30 000-40 000 
temporary cements with pain-relieving properties, antiseptic preparations, chemical methods, physical methods, e.g. laser therapy, are used. ${ }^{29}$ Despite the existence of many methods and protocols used to treat pain caused by dentine sensitivity, no ideal solution has yet been found that would relieve pain quickly, act with great force and for a long time. ${ }^{30} \mathrm{~A}$ study was conducted in which the authors checked the influence of selected chemical and physical methods on the structure of exposed dentine after teeth were prepared for metal crowns. ${ }^{31}$ The study included fifty human teeth, which after extraction were subjected to a standard process of preparation for metal crowns using a numerically controlled computer. Next, each tooth was treated with a different preparation: glutaraldehyde, casein phosphoptide (CPP) - amorphous calcium phosphate (ACP), laser rays, Pro-Argin. Next, metal crowns were cemented on prepared teeth with a glass ionomer cement. After 48 hours of incubation at $37^{\circ} \mathrm{C}$ the retention of prosthetic restorations was examined. It was observed that teeth covered with Pro-Argin and CPPACP polishing paste showed the highest bond strength in comparison with "virgin dentine" (not coated with any desensitiser). The fact that the best desensitising effects were achieved in this study in teeth treated with Tooth Mousse toothpaste may be attributed to the change in dentine structure. However, slightly higher dentine sensitivity levels in the current study (expressed on the VAS scale) in the control study conducted 3 days after the application of chemical preparations may result from potential bacterial contamination of exposed dentine by inflammatory mediators during the metal or zirconium base control. Their increased synthesis lowers the pain threshold. Haluk Baris Kara et al. evaluated the effectiveness of biostimulation laser therapy and glutar aldehyde in pain management after the preparation of 76 teeth in 20 patients kanalików zębinowych przypada na $1 \mathrm{~mm}^{2}$ zębiny). ${ }^{24}$ Obnażona zębina narażona zostaje na bezpośrednie działanie czynników środowiska zewnętrznego i przenikanie szkodliwych bodźców do miazgi zęba. W związku z tym najczęstszymi powikłaniami rehabilitacji protetycznej przeprowadzonej za pomocą stałych uzupełnień protetycznych jest utrata żywotności miazgi, zapalenie dziąseł lub zwiększona wrażliwość zębiny. ${ }^{25,26}$ Istnieje ścisła korelacja pomiędzy stopniem wrażliwości zębiny, a liczbą i średnicą otwartych kanalików. ${ }^{24}$ $\mathrm{W}$ jednym $\mathrm{z}$ randomizowanych badań autorzy dokonali oceny rodzaju i częstości występowania powikłań po leczeniu z zastosowaniem koron protetycznych osadzonych na filarach z użyciem różnych cementów. Stwierdzono występowanie ciężkiej postaci nadwrażliwości zębiny, która wymagała leczenia endodontycznego w 7,4\% zębów poddanych zabiegowi szlifowania. ${ }^{27}$ Do rozwoju wrażliwości zębiny może dojść po zacementowaniu stałych długoczasowych uzupełnień protetycznych np. osadzonych za pomocą cementu szklano-jonomerowego. Kwas poliakrylowy zawarty w cemencie lutującym może poszerzyć kanaliki zębinowe i wzmagać ruch płynu, który będzie podrażnić zakończenia włókien czuciowych w miazdze zęba. ${ }^{28} \mathrm{~W}$ celu zmniejszenia wrażliwości pozabiegowej stosuje się korony tymczasowe, cementy tymczasowe o właściwościach łagodzących ból, preparaty antyseptyczne, metody chemiczne, fizyczne np. laseroterapie. ${ }^{29}$ Pomimo istnienia wielu metod i schematów stosowanych w leczeniu dolegliwości bólowych wywołanych wrażliwością zębiny dotychczas nie znaleziono idealnego środka, który znosiłby ból szybko, działał z dużą siłą i długoczasowo. ${ }^{30}$ Były wykonywane badania, w których autorzy sprawdzali wpływ wybranych metod chemicznych i fizycznych na strukturę obnażonej zębiny po opracowaniu zębów pod korony metalowe. ${ }^{31}$ Badaniem objęto 50 ludzkich zębów, które po ekstrakcji 
treated with prosthetic crowns. ${ }^{32}$ They observed comparable therapeutic efficacy of both methods and recommended them for prophylactic use after tooth grinding in order to obliterate exposed dentine tubules and protect the pulp from irritation. The authors of another study evaluated the effect of calcium phosphate suspension on dentine sensitivity before and immediately after tooth polishing, before placement of target crowns and 1 week and 1 month after cementation of permanent crowns on teeth prepared for allceramic crowns. They achieved a significant reduction in tooth sensitivity compared to the placebo effect. The above-mentioned authors recommend the use of calcium phosphate to reduce pain after the procedure of tooth grinding and cementation of permanent crowns. ${ }^{33}$

There are many factors that may interfere with or modify the results of pain measurement of dentine hypersensitivity. Dentine hypersensitivity is a self-limited disorder due to production of tertiary or sclerotic dentine. The placebo effect may also have quite a big influence on the obtained results. ${ }^{34,35}$ The above factors may also have affected the value of the results obtained in the current study.

\section{Conclusions}

1. The best clinical efficacy in eliminating pain in exposed dentine resulting from the preparation of teeth for fixed restorations was demonstrated by combined preparations, i.e. Tooth Mousse and Green Or.

2. Compound preparations may be the first choice medication among chemical methods of alleviating dentinal hypersensitivity in patients treated prosthetically. poddano standardowemu procesowi opracowanoia pod korony metalowe za pomocą komputera sterowanego numerycznie. Następnie na każdy ząb aplikowano poszczególne preparaty: aldehyd glutarowy, fosfopeptyd kazeiny (CPP) - amorficznego fosforanu wapnia (ACP), promienie lasera, Pro-Argin. Następnie zacementowano na oszlifowanych zębach korony metalowe za pomoca cementu glasjonomerowego. Po 48 godzinnej inkubacji w temp. $37^{\circ} \mathrm{C}$ zbadano retencję uzupełnień protetycznych. Zaobserwowano, że największą siłę wiązania w porównaniu z ,zębiną dziewiczą” (nie pokrytą żadnym środkiem odczulającym) wykazywały zęby, pokryte pastą polerską ProArgin i CPP-ACP. Zmiana struktury zębiny może tłumaczyć fakt osiągnięcia najlepszych efektów desensytyzujących w niniejszym badaniu w zębach poddanych terapii pastą Tooth Mousse. Natomiast uzyskanie nieco wyższych wyników poziomu wrażliwości zębiny w obecnej pracy (wyrażonej w skali VAS) w badaniu kontrolnym przeprowadzonym po 3 dniach od aplikacji preparatów chemicznych może wynikać z potencjalnego skażenia bakteryjnego obnażonej zębiny w czasie kontroli podbudowy metalowej lub cyrkonowej, przez mediatory zapalne. Wzmożona ich synteza obniża bowiem próg bólowy. Haluk Baris Kara i wsp. oceniali skuteczność laseroterapii biostymulacyjnej i aldehydu glutarowego w znoszeniu bólu po opracowaniu 76 zębów u 20 pacjentów leczonych $\mathrm{z}$ zastosowaniem koron protetycznych. ${ }^{32}$ Zaobserwowali porównywalną skuteczność terapeutyczną obu metod i rekomendowali je do profilaktycznego stosowania po oszlifowaniu zębów w celu obliteracji odsłoniętych kanalików zębinowych i zabezpieczenia miazgi przed podrażnieniem. Autorzy innej pracy dokonali oceny wpływu wodnej zawiesiny fosforanów wapnia na wrażliwość zębiny przed oszlifowaniem zębów oraz bezpośrednio po aplikacji preparatu, przed osadzeniem koron docelowych oraz po 1 tygodniu 
i 1 miesiącu od zacementowania koron długoczasowych na zębach opracowanych pod korony całoceramiczne. Uzyskali znaczną redukcję wrażliwości zębów w porównaniu z efektem placebo. W/w autorzy zalecają używanie w/w środka chemicznego do redukcji dolegliwości bólowych po zabiegu szlifowania zębów i zacementowaniu koron długoczasowych. ${ }^{33}$

Istnieje wiele czynników, które mogą zakłócać lub modyfikować uzyskane wyniki pomiaru natężenia bólu w nadwrażliwości zębiny. Nadwrażliwość zębiny jest schorzeniem, które charakteryzuje się tendencją do samoistnego zdrowienia z upływem czasu (wytwarzanie zębiny trzeciorzędowej, sklerotycznej). Dosyć duży wpływ na otrzymane wyniki może wywierać również efekt placebo. ${ }^{34,35}$ Powyższe czynniki mogły również wpłynąć na wartość uzyskanych wyników w obecnej pracy.

\section{Wnioski}

1. Najlepszą skuteczność kliniczną w znoszeniu dolegliwości bólowych obnażonej zębiny powstałej w wyniku opracowania zębów pod uzupełnienia stałe wykazywały preparaty złożone: pasta Tooth Mousse i preparat Green Or.

2. Preparaty złożone mogą być środkami z wyboru spośród chemicznych metod znoszenia nadwrażliwości zębiny u pacjentów leczonych protetycznie.

\section{References / Piśmiennictwo}

1. Sztogryn M, Jodkowska E: Ocena skuteczności produktów znoszących nadwrażliwość zębiny na podstawie doświadczeń autorów polskich. Magazyn Stomat 2007; 4: 42-44.

2. Zielińska-Zborowska J, Buczkowska-Puślecka P, Wędrychowicz-Welman A, Mrall-Wechta M: Etiologia i diagnostyka nadwrażliwości zębiny - przegląd piśmiennictwa. Dental Forum 1/2014/XLII.

3. Cummins D: Dentin hypersensitivity: From Diagnosis to a breakthrough therapy for everyday sensitivity relief. J Clin Dent 2009; 20, Spec. Iss., 1-9.

4. Bartold PM: Dentinal hypersensitivity: a review. Austr Dent J 2006; 51(3): 212-218.

5. Kaczmarek U, Janowska K: Effektywność kliniczna pasty Sensitivite Pro-Relief w znoszeniu nadwrażliwości zębiny. Czas Stomat 2009; 62(9): 701-710.

6. Kogut A: Ozonoterapia w praktyce stomatologicznej. Mag Stomat 2007; 9: 112-118.

7. Chatas $R$ i wsp.: Zastosowanie ozonu w leczeniu zwiększonej wrażliwości zębiny.
Doniesienie wstępne. Dental Forum 2/11, XXXIX.

8. Jodkowska E, Sowa J: Związki fluoru w leczeniu nadwrażliwości zębiny w świetle piśmiennictwa. Magazyn Stomat 2008; 4: 4044.

9. Sykes LM: Dentine hypersensitivity: a review of its etiology, pathogenesis and management. SADJ 2007; 62(2): 66-71.

10. Addy M, West NX: The role of toothpaste in the aetiology and treatment of dentine hypersensitivity. Monogr Oral Sci 2013; 23: 75-87.

11. Parolia A, Kundabala M, Mohan M: Management of dentinal hypersensitivity: a review. J Calif Dent Assoc 2011; 39(3): 167179.

12. Yesilyurt C, Sezer U, Ayar MK, Alp CK, Tasdemir T: The effect of a new calciumbased agent, Pro-Argin, on the microhardness of bleached enamel surface. Aust Dent J 2013; 58(2): 207-212.

13. Orchardson R, Gillam DG: Managing dentin 
hypersensitivity. J Am Dent Assoc 2006; 137(7): 990-998.

14. Kaczmarek U, Jankowska K, Filipowski H: Ocena skuteczności klinicznej pasty desensytyzującej zawierającej argininę w znoszeniu nadwrażliwości zębiny. Dent Med Probl 2010; 47(4): 441-449.

15. Sadkowski A: Nadwrażliwość zębiny - etiologia i leczenie. Stomatologia Współczesna 2007; Supl.1: 28-35.

16. Gusmao ES, Coelio R, Faruas BC, Cimoes $R$ : Dentin hypersensitivity before and after periodontal treatment. Acta Stomatol Croat 2010; 44(4): 251-261.

17. Canakci CF, Canakci V: Pain experienced by patients undergoing different periodontal therapies. J Am Dent Assoc 2007; 138(12): 1563-1573.

18. West N, Seong J, Davies M: Dentine hypersensitivity. Monogr Oral Sci 2014; 25: 108-122.

19. Bamise CT, Esan TA: Mechanisms and treatment approaches of dentine hypersensitivity: a literature review. Oral Health Prev Dent 2011; 9(4): 353-367.

20. Mantzourani $M$, Sharma D: Dentine sensitivity: past, present and future. J Dent 2013; 41(4); 3-17.

21. Barbosa FM, Cabral D, Kabadayan F, et al.: Depressive behawior induced by unpredictable mild stress increases dentin hypersensitivity in rats. Arch Oral Biol 2017; 80: 164-174.

22.Bergamini MR, Kabadayan F, Bernardi $M M$, et al.: Stress and its role in the dentin hypersensitivity in rats. Arch Oral Biol 2017; 73: 151-160.

23. Bodian $C A$, Freedman $G$, Hossain $S$, et al.: The visual analog scale for pain: clinical significance in postoperative patients. Anesthesiology 2001; 95: 1356-61.

24. Richardson D, Tao L, Pashley DH: Dentin permeability:effects of crown preparation. Int J Prosthodont 1991; 4: 219-225.
25.S Opal, S Garg, A Dhindsa, T. Taluja: Minimally invasive clinical approach in indirect pulp therapy and healing of deep carious lesions. J Clin Pediatr Dent 2014; 38(3): 185-192.

26. Pihlaja J, Napankangas R, Raustia A: Early complications and short-term failures of zirconia single crowns and partial fixed dental prostheses. J Prosthet Dent 2014; 112(4): 778783.

27. Selz CF, Strub JR, Vach K, Guess PC: Long -term performance of posteriori Inceram Alumina crowns cemented with different luting agents: a prospective, randomized cloinmical split-mouth study over 5-years. Clin Oral Investig 2014; 18(6): 1695-1703.

28. Adrianes PA, Boever JA, Loesche WJ: Bacterial invasion in root cementum and radicular dentin of periodontally diseased teeth in humans: a resorvoir of periodontopathic bacteria. J. Periodontol 1988; 59: 222-230.

29. Bannister RD, Roudsari RV, Satterthwaite $J D$ : Film thickness of dentin desensitizing agents on fullcrown preparations: influence of product and gravity. Oper Dent 2014; 39: 241-249.

30. Lin PY, Cheng YW, Chu CY, Lin CP, Tu YK: In - office treatment for dentin hypersensitivity: a systematic review and network metaanalysis. J Clin Periodontol 2013; 40: 53-54.

31. Chandavarkar, Saili M, Ram, Sabita M: A comparative evaluation of the effect of dentin desensitizers on the retention of complete cast metal crowns. Contemporary Clinical Dentistry 2015; Supl. 1, 6: 45-50.

32. Haluk Baris Kara, Umut Cakan, Burcu Yilmaz, Pelin Inan Kurugol: Efficacy of diode laser and gluma on post- preparation sensitivity: a randomized split - mouth clinical study. Journal of Esthetic\&Restorative Dentistry 2016; 28(6): 405-411.

33. Shetty Rohit, Bhat Adarsh N, Mehta Deepak, Finger Wernet $J$ : Effect of a calcium phosphatate desensitizer on pre-and postcemention 
sensitivity of teeth prepared for full-coverage restorations:a randomized, placebo controlled clinical study. Int J Prosthodont 2017; 30(1): 38-42.

34. Yates R, West N, Addy M, Marlow I: The effects of a potassium citrate, cetylpyridinium chloride, sodium fluoride mouthrinse on dentine hypersensitivity, plaque and gingivitis. A placebo-controlled study. J Clin Periodontol 1998; 25: 813-820.
35. Lima Franca-Grohmann I, Menck Sangiorgio JP, Corręa Viana $R$, et al.: Dentin hypersensitivity reduction using an arginine-based approach after nonsurgicalperiodontal treatment. Am J Dent 2016; 29(5): 271-276.

Zaakceptowano do druku: 19.09.2019 r.

Adres autorów: 02-097 Warszawa, ul. Binieckiego 6.

(C) Zarząd Główny PTS 2019. 